\title{
Research Article Effect of Extruding Full-Fat Soy Flakes on Trans Fat Content
}

\author{
Hongxia Feng, ${ }^{1}$ Xiaonan Sui, ${ }^{1,2}$ Yunhe Chang, ${ }^{3}$ Baokun Qi, ${ }^{1}$ Yan Zhang, ${ }^{1,2}$ \\ Yang Li, ${ }^{1}$ and Lianzhou Jiang ${ }^{1}$ \\ ${ }^{1}$ College of Food Science, Northeast Agricultural University, Harbin 150030, China \\ ${ }^{2}$ School of Science, The National University of Singapore, Singapore 119077 \\ ${ }^{3}$ Research Institute of Food and Beverage, Wahaha Group Co. Ltd., Hangzhou 310018, China
}

Correspondence should be addressed to Yang Li; 284789219@qq.com and Lianzhou Jiang; jianglianzhousci@163.com

Received 8 May 2014; Revised 15 July 2014; Accepted 28 July 2014; Published 19 August 2014

Academic Editor: Alberto A. Iglesias

Copyright (C) 2014 Hongxia Feng et al. This is an open access article distributed under the Creative Commons Attribution License, which permits unrestricted use, distribution, and reproduction in any medium, provided the original work is properly cited.

\begin{abstract}
To evaluate the effects of extrusion process on the trans fatty acids (TFAs) formation in soybean crude oils, three different extrusion parameters, namely, extrusion temperature $\left(80-160^{\circ} \mathrm{C}\right)$, feed moisture $(10-26 \%)$, and screw speed (100-500 rpm), were carried out. It was found that only five different types of TFAs were detected out using gas chromatography-mass spectrometry. Before the extrusion started, the initial amount of total TFAs was $3.04 \mathrm{~g} / 100 \mathrm{~g}$. However, after extruding under every level of any variable, the total amounts of TFAs were significantly higher than those in the control sample $(P<0.05)$. For example, taking the effect of extrusion temperature into account, we can find that the highest amount of total of trans fatty acid (TTFA) was 1.62 times the amount of that in the control sample, whereas the lowest amount of TTFA was 1.54 times the amount of that in the control sample. Importantly, it was observed that the amounts of every type of trans fatty acid were not continuously increasing with the increase of the level of any extrusion variable. This phenomenon demonstrated that the formation and diversification were intricate during extruding process and need to be further studied.
\end{abstract}

\section{Introduction}

Trans fatty acids (TFAs) are geometrical isomers of unsaturated fatty acids containing nonconjugated carbon-carbon double bonds possessing the trans-configuration [1]. Epidemiologic and clinical studies have revealed that the consumption of TFAs can lead to a higher risk of coronary heart disease, sudden death, and diabetes mellitus $[2,3]$. Therefore, a minimal intake of TFAs was recommended to lower the associated health risks [2-4].

Previous studies have suggested that low level of TFAs in diet might derive from microbial biohydrogenation in the digestive tract of ruminant animals, whilst high level of TFAs is mainly produced through the consumption of partially hydrogenated edible oils in processed products $[5,6]$. TFAs can also be produced during the oil refining process owing to the high temperature used in the deodorization procedure [7]. Crude oils are commonly used as raw materials for hydrogenation and refinement to prepare edible oils, and the consequent TFA content of the edible oils is affected by the original TFA level in the crude oil feedstock. It is necessary to control the TFA content of crude oil feedstock. However, to increase oil yields, oil seeds are often subjected to pretreatments, such as flaking, cooking, extruding, and ultrasound, prior to the extraction process. A recent work showed that the extrusion of oil seeds may lead to a complete disruption of cellular structure in favor of increasing the oil extraction yield [8]. Extrusion pretreatment process is still a complicated multi-input-output system and has a complicated impact on the product properties. Several studies have reported the influence of extrusion on the yield and the physicochemical properties of crude oils [9-14]. Lamsal et al. reported that the oil extraction recovery was increased from $68 \%$ to $88 \%$ after treatment with extrusion [12]. Wang and Johnson found that crude soybean oil from extruding process was low in phosphorus, FFA contents, and the oxidative stabilities [14]. In addition, the nutritional value of lipids could be affected during extrusion as a result of oxidation, hydrogenation, isomerization, or polymerization. According to Maga, the extent of hydrogenation and cis- to trans-isomerization of 
fatty acids that takes place during extrusion is too small to be nutritionally significant $[15,16]$. Furthermore, Xu et al. observed that a high-temperature-microtime-treated diet with extruded soybean increased the level of trans-10, cis-12 conjugated linoleic acid, which may inhibit lipogenesis in the intramuscular fat of Holstein steers [17]. However, the effect of extrusion variables on TFA content in crude oil has rarely been studied. Therefore, the primary purpose of the study was to determine the TFAs content in the crude oil.

Nowadays crude oils are conventionally extracted using an organic solvent such as hexane or ether which might have environmental and safety implications. With concerns on safety and environmental issues, numerous research groups have been interested in using the enzyme-assisted aqueous extraction processing (EAEP) method, as an environmentally friendly alternative to solvent extraction. For EAEP, water is used as an extracting medium to remove oil as an emulsion or free oil unlike organic solvents, which dissolve the oil. Simultaneously, the enzymatic hydrolysis of proteins in the cell walls and pseudomembranes surrounding the oil bodies is conducive to enhance the oil yield [8]. Moreover, the crude oil obtained by the method of EAEP was reported to be partially degummed oil with very low phosphorus content and, thus, was suitable for physical refining [18]. Due to these advantages, in the present study, EAEP was applied for the extraction of the crude oil. In order to enhance the oil yield, a twin-screw extruder was applied prior to the EAEP of crude oil from full-fat dehulled soybean flakes. The aim of this work was to study the effect of extrusion technology on the formation and the content of TFAs in the crude oil.

\section{Materials and Methods}

2.1. Materials and Reagents. Full-fat, dehulled soybean flakes containing $7.3 \%$ moisture and $16.5 \%$ oil were obtained from Fengzheng Soybean Food Co. Ltd. (Dunhua, China) in 2013. Protex 6L (2.4 AU/g, from Bacillus licheniformis) was purchased from Novo-Nordisk A/S (Bagsvaerd, Denmark). cis-/trans-Linoleic acid methyl ester mix (Catalog number 47791), linolenic acid methyl ester isomer mix (Catalog number 47792), trans-6-octadecenoic methyl ester (Catalog number 47199), methyl elaidate (Catalog number 45119-1mL), and trans-11-octadecenoic methyl ester (Catalog number 46905-U) were purchased from Sigma-Aldrich (St. Louis, USA). All other chemicals and reagents were obtained from commercial suppliers and are of analytical grade.

2.2. Sample Preparation. Dehulled soybean flakes were extruded using an EV-25 twin-screw extruder (Clextral, made in France) in the set conditions described in Table 1. In order to study the effect of the three variables, namely, extrusion temperature, feed moisture, and screw rotational speed, extruding was implemented via three groups of run. When one variable was controlled, the other two were fixed at a certain value. For example, to study the effect of extrusion temperature on the content of trans fatty acid in the oil from the sample, the two variables of feed moisture and screw rotational speed were fixed at the value of $14 \%$ and
TABLE 1: The extrusion parameters for full-fat, dehulled soybean flakes.

\begin{tabular}{lccc}
\hline Groups of run & \multicolumn{3}{c}{ Variables $^{\mathrm{a}}$} \\
\hline \multirow{3}{*}{1} & $T$ & $F$ & $R$ \\
\hline & 100 & 14 & 200 \\
& 120 & 14 & 200 \\
& 140 & 14 & 200 \\
& 160 & 14 & 200 \\
& 100 & 14 & 200 \\
\hline \multirow{3}{*}{3} & 100 & 10 & 200 \\
& 100 & 14 & 200 \\
& 100 & 18 & 200 \\
& 100 & 22 & 200 \\
& 100 & 26 & 200 \\
\hline & 100 & 14 & 100 \\
& 100 & 14 & 200 \\
& 100 & 14 & 300 \\
& 100 & 14 & 400 \\
& & 14 & 500 \\
\hline
\end{tabular}

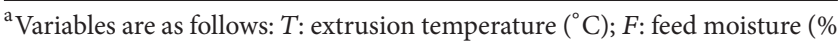
wet basis); $R$ : screw rotational speed (rpm).

$200 \mathrm{rpm}$, respectively, according to the parameters factory usually applied. Then the extrusion temperature (ranged from 80 to $160^{\circ} \mathrm{C}$ ) was adjusted to the set value one by one and from low to high. During the adjustment, the extruder was continuously operational. Until the extruder was stabilized at the set condition (e.g., $80^{\circ} \mathrm{C}$ ), the extrudates were sampling. After the extrusion pretreatment process, the press strips were allowed to cool to ambient temperature and ground into a fine powder. The powder was subsequently used for oil extraction using the EAEP method according to the previous work of our group [19]. The extracting experiment for preparing oil sample from extrudates obtained from each extruding run was conducted in triplicate. The oil samples obtained were stored in dark bottles without headspace at $-20^{\circ} \mathrm{C}$ prior to analysis.

\subsection{Determination of Trans Fatty Acid Content in Soybean Oil.} Fatty acid methyl esters (FAMEs) were prepared according to the method previously reported by our group [19]. After $O$-methylation, the FAMEs were separated and quantified by gas chromatography-mass spectrometry (GC-MS) using an Agilent model 6890-5973 GC-MS equipped with a flame ionization detector and HP-88 fused silica capillary column $(100 \mathrm{~m} \times 0.25 \mathrm{~mm}$ i.d. $\times 0.2 \mu \mathrm{m}$ film thickness $)$. Helium was used as the carrier gas at a flow rate of $1 \mathrm{~mL} / \mathrm{min}$ and the detector temperature was $250^{\circ} \mathrm{C}$. The split ratio was $30: 1$ and the column temperature was programmed as follows: (i) the initial oven temperature was $80^{\circ} \mathrm{C}$ and it was maintained at $80^{\circ} \mathrm{C}$ for $5 \mathrm{~min}$; (ii) the oven temperature increased to $150^{\circ} \mathrm{C}$ at a rate of $10^{\circ} \mathrm{C} / \mathrm{min}$ and was maintained at $150^{\circ} \mathrm{C}$ for $2 \mathrm{~min}$; (iii) the oven temperature increased to $230^{\circ} \mathrm{C}$ at a rate of $5^{\circ} \mathrm{C} / \mathrm{min}$ and was maintained at $230^{\circ} \mathrm{C}$ for $10 \mathrm{~min}$. The individual fatty acids were identified by comparison of the retention times with preprepared standards and quantified using an external 
TABLE 2: Trans fatty acid composition in soybean oil extracted by EAEP from extrudates at various extrusion temperatures under the condition of fixed feed moisture (14\%) and rotational screw speed (200 rpm).

\begin{tabular}{|c|c|c|c|c|c|c|}
\hline \multirow{2}{*}{ Fatty $\operatorname{acids}^{B}(g / 100 g)$} & \multicolumn{6}{|c|}{ Extrusion temperature $\left({ }^{\circ} \mathrm{C}\right)$ (pressure (bar)) } \\
\hline & Control $^{\mathrm{A}}(1.0133)$ & $80(9.9113)$ & $100(2.2745)$ & $120(2.1050)$ & $140(8.0125)$ & $160(12.0500)$ \\
\hline $\mathrm{C} 18: 1,9 \mathrm{t}$ & $0.57 \pm 0.01^{\mathrm{d}}$ & $0.41 \pm 0.01^{e}$ & $2.09 \pm 0.04^{\mathrm{a}}$ & $1.78 \pm 0.02^{\mathrm{c}}$ & $1.91 \pm 0.03^{\mathrm{b}}$ & $2.07 \pm 0.04^{\mathrm{a}}$ \\
\hline $\mathrm{C} 18: 2,9 \mathrm{c}, 12 \mathrm{t}$ & $0.64 \pm 0.01^{\mathrm{d}}$ & $1.61 \pm 0.02^{\mathrm{a}}$ & $0.74 \pm 0.01^{\mathrm{c}}$ & $0.82 \pm 0.01^{\mathrm{b}}$ & $0.84 \pm 0.01^{\mathrm{b}}$ & $0.76 \pm 0.00^{c}$ \\
\hline $\mathrm{C} 18: 2,9 \mathrm{t}, 12 \mathrm{c}$ & $0.11 \pm 0.01^{\mathrm{c}}$ & $0.84 \pm 0.01^{\mathrm{a}}$ & $0.07 \pm 0.01^{\mathrm{d}}$ & $\mathrm{ND}^{\mathrm{C}}$ & $0.21 \pm 0.01^{\mathrm{b}}$ & $0.09 \pm 0.00^{\mathrm{d}}$ \\
\hline Total trans-C18:2 & $0.74 \pm 0.01^{\mathrm{d}}$ & $2.44 \pm 0.05^{\mathrm{a}}$ & $0.81 \pm 0.01^{\mathrm{c}}$ & $0.82 \pm 0.01^{\mathrm{c}}$ & $1.05 \pm 0.01^{\mathrm{b}}$ & $0.85 \pm 0.01^{\mathrm{c}}$ \\
\hline $\mathrm{C} 18: 3(9 t, 2 t, 15 c+9 t, 12 c, 15 t)$ & $0.68 \pm 0.01^{\mathrm{b}, \mathrm{c}}$ & $0.69 \pm 0.01^{\mathrm{b}}$ & $0.68 \pm 0.01^{\mathrm{b}, \mathrm{c}}$ & $0.70 \pm 0.01^{\mathrm{a}}$ & $0.69 \pm 0.01^{\mathrm{b}}$ & $0.67 \pm 0.01^{\mathrm{c}}$ \\
\hline $\mathrm{C} 18: 3,9 \mathrm{c}, 12 \mathrm{c}, 15 \mathrm{t}$ & $1.05 \pm 0.01^{\mathrm{e}}$ & $1.14 \pm 0.01^{\mathrm{d}}$ & $1.30 \pm 0.02^{\mathrm{b}}$ & $1.40 \pm 0.02^{\mathrm{a}}$ & $1.25 \pm 0.02^{\mathrm{c}}$ & $1.32 \pm 0.02^{\mathrm{b}}$ \\
\hline Total trans-C18:3 & $1.73 \pm 0.02^{\mathrm{d}}$ & $1.82 \pm 0.03^{c}$ & $1.98 \pm 0.04^{\mathrm{b}}$ & $2.10 \pm 0.04^{\mathrm{a}}$ & $1.94 \pm 0.04^{\mathrm{b}}$ & $1.99 \pm 0.04^{\mathrm{b}}$ \\
\hline TTFA $^{\mathrm{D}}$ & $3.05 \pm 0.06^{\mathrm{d}}$ & $4.67 \pm 0.09^{\mathrm{b}, \mathrm{c}}$ & $4.87 \pm 0.10^{\mathrm{a}, \mathrm{b}}$ & $4.71 \pm 0.09^{\mathrm{b}, \mathrm{c}}$ & $4.90 \pm 0.10^{\mathrm{a}}$ & $4.91 \pm 0.10^{\mathrm{a}}$ \\
\hline
\end{tabular}

${ }^{\mathrm{A}}$ Control: fresh oil from unextruded soybean flakes.

${ }^{\mathrm{B}}$ Mean of duplicate analyses \pm standard deviation.

${ }^{\mathrm{C}} \mathrm{ND}$ : not detected.

${ }^{D}$ TTFA: total of trans fatty acids.

${ }^{\mathrm{a}-\mathrm{f}}$ Symbols bearing different letters in the same row are significantly different $(P<0.05)$.

standard. The analysis of each oil sample was conducted in triplicate, and the mean value was used for the later variance analysis.

2.4. Statistical Analysis. Experiments were performed in triplicate and results were expressed as mean \pm standard deviation (SD). Data were subjected to the one-way analysis of variance (ANOVA) and the significance was defined at $P<0.05$. The variance analysis was conducted using SPSS (statistical program for social sciences, SPSS Corporation, Chicago, IL, USA; version 16.0 for Windows).

\section{Results and Discussion}

3.1. GC-MS Analysis of the TFA Standard Mixtures. The GCMS chromatogram of the TFA methyl ester standards is shown in Figure 1 . A total of 16 peaks, including $2 \times$ cisunsaturated fatty acids, $13 \times$ trans fatty acids, and internal standards $(\mathrm{Cl} 17: 0$; $\mathrm{RT}=19.78)$, were resolved within $22 \mathrm{~min}$. We failed to achieve baseline separation of the trans-isomers of oleic acid (peaks: 6t, 9t, and 11t) and linolenic acid (peaks: $9 \mathrm{t}, 12 \mathrm{t}$, and $15 \mathrm{c} ; 9 \mathrm{t}, 12 \mathrm{c}$, and $15 \mathrm{t} ; 9 \mathrm{c}, 12 \mathrm{t}$, and $15 \mathrm{t}+9 \mathrm{c}, 12 \mathrm{c}$, and $15 t$; and $9 c, 12 t$, and $15 c)$ through a single run of chromatography. The TFAs are eluted prior to their corresponding cisisomers, because a capillary column was used as a cyanoalkyl polysiloxane polar stationary phase. For example, the transisomers of linoleic acid (C18:2, 9t, 12t; C18:2, 9c, 12t) were eluted prior to the cis-isomers of linoleic acid (C18:2, 9c, 12c). The partially overlapped peaks corresponding to transisomers did not affect the quantitative analysis, since for food labeling these isomers are regarded as a representation of the total amount of trans-oleic acid or trans-linolenic acid. Nevertheless, this method is an improvement in terms of retention time compared to those previously reported [20].

\subsubsection{Effect of Different Extruding Parameters on the TFA} Content. In this study, we focused on the formation of the TFAs bearing 18 carbon atoms which are the most representative in the samples. The main TFA isomers found in the

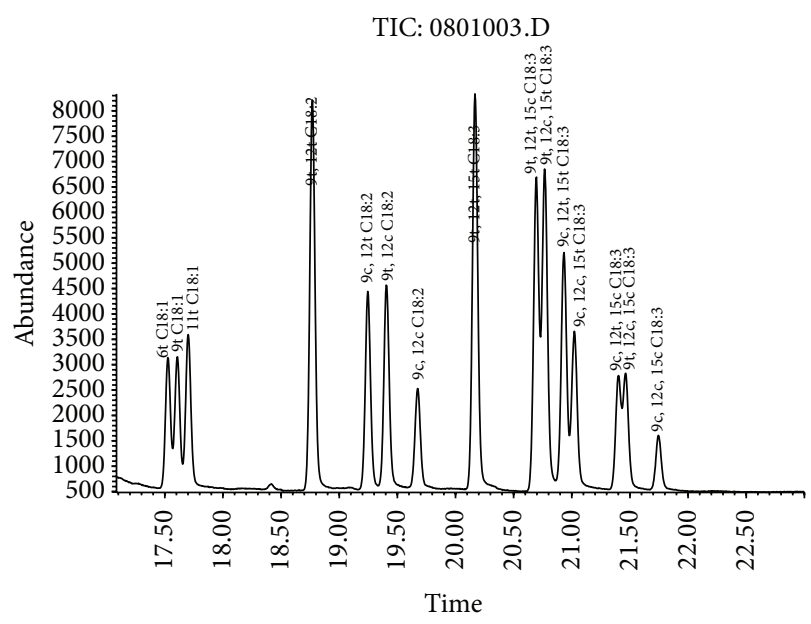

FIGURE 1: The GC-MS chromatogram of TFA methyl ester standards. Retention time (RT; min) of each standard compound was as follows: C18:1, 6t (17.32); C18:1, 9t (17.41); C18:1, 11t (17.50); C18:2, 9t, $12 \mathrm{t}$ (18.54); C18:2, 9c, 12t (19.02); C18:2, 9t, 12c (19.17); C18:2, 9c, 12c (19.45); C18:3, 9t, 12t, 15t (19.92); C18:3, 9t, 12t, 5c (20.45); C18:3, 9t, 12c, 15t (20.53); C18:3, 9c, 12t, 15t (20.68); C18:3, 9c, 12c, 15t (20.78); C18:3, 9c, 12t, 15c (21.15); C18:3, 9t, 12c, 15c (21.22); C18:3, 9c, 12c, 15c (21.50).

control samples were isomers of C18:1, $9 \mathrm{t}(0.57 \mathrm{~g} / 100 \mathrm{~g})$; C18:2, 9c, 12t (0.64 g/100 g); C18:2, 9t, 12c (0.11 g/100 g); C18:3, 9t, $12 \mathrm{t}, 15 \mathrm{c} / 9 \mathrm{t}, 12 \mathrm{c}, 15 \mathrm{t}(0.68 \mathrm{~g} / 100 \mathrm{~g})$; and $\mathrm{C} 18: 3,9 \mathrm{c}, 12 \mathrm{c}, 15 \mathrm{t}$ $(1.05 \mathrm{~g} / 100 \mathrm{~g})$ (Tables $2-4)$. The TFAs of C18:1, 6t; C18:1, 11t; $\mathrm{C} 18: 2,9 \mathrm{t}, 12 \mathrm{t}$; C18:3, 9t, 12t, 15t; C18:3, 9c, 12t, 15t; C18:3, $9 \mathrm{c}, 12 \mathrm{t}, 15 \mathrm{c}$; and $\mathrm{C} 18: 3,9 \mathrm{t}, 12 \mathrm{c}, 15 \mathrm{c}$ were not detected in all the tested samples. In our study, the initial amount of total TFAs in the control samples was $3.04 \mathrm{~g} / 100 \mathrm{~g}$ of extracted soy oil (Tables 2-4). In a previous study, the amounts of TFAs were reported to be $0.26-0.82 \mathrm{~g} / 100 \mathrm{~g}$ in soybean oil [21]. Higher TFA content $(1.15-3.11 \mathrm{~g} / 100 \mathrm{~g})$ in soybean oil was also reported [4]. Hou et al. also reported the values of TFAs in rapeseed oil (1.37-3.82 g/100 g), sunflower oil (1.41$2.10 \mathrm{~g} / 100 \mathrm{~g})$, and corn oil different range (2.01-4.76 g/100 g). 
TABLE 3: Trans fatty acid composition of soybean oil extracted by EAEP from extrudates at various feed moisture levels under the condition of fixed extrusion temperature $\left(100^{\circ} \mathrm{C}\right)$ and rotational screw speed $(200 \mathrm{rpm})$.

\begin{tabular}{|c|c|c|c|c|c|c|}
\hline \multirow{2}{*}{ Fatty acids ${ }^{\mathrm{B}}(\mathrm{g} / 100 \mathrm{~g})$} & \multicolumn{6}{|c|}{ Feed moisture (\%) (pressure (bar)) } \\
\hline & Control $^{\mathrm{A}}(1.0133)$ & $10(16.0825)$ & $14(2.2745)$ & $18(2.8938)$ & $22(0.2213)$ & $26(0.2413)$ \\
\hline $\mathrm{C} 18: 1,9 \mathrm{t}$ & $0.57 \pm 0.01^{\mathrm{e}}$ & $1.84 \pm 0.03^{c}$ & $2.09 \pm 0.04^{\mathrm{a}}$ & $2.00 \pm 0.04^{\mathrm{a}, \mathrm{b}}$ & $1.71 \pm 0.03^{\mathrm{d}}$ & $1.96 \pm 0.04^{\mathrm{b}}$ \\
\hline $\mathrm{C} 18: 2,9 \mathrm{c}, 12 \mathrm{t}$ & $0.64 \pm 0.01^{\mathrm{e}}$ & $0.72 \pm 0.01^{\mathrm{b}}$ & $0.74 \pm 0.01^{\mathrm{b}}$ & $0.69 \pm 0.01^{c}$ & $0.63 \pm 0.01^{e}$ & $0.78 \pm 0.01^{\mathrm{a}}$ \\
\hline $\mathrm{C} 18: 2,9 \mathrm{t}, 12 \mathrm{c}$ & $0.11 \pm 0.01^{\mathrm{b}}$ & $\mathrm{ND}^{\mathrm{C}}$ & $0.07 \pm 0.01^{\mathrm{c}}$ & $0.07 \pm 0.01^{c}$ & ND & $0.21 \pm 0.01^{\mathrm{a}}$ \\
\hline Total trans-C18:2 & $0.74 \pm 0.01^{c}$ & $0.72 \pm 0.01^{\mathrm{c}}$ & $0.81 \pm 0.02^{\mathrm{b}}$ & $0.76 \pm 0.01^{\mathrm{c}}$ & $0.63 \pm 0.01^{\mathrm{d}}$ & $0.99 \pm 0.02^{\mathrm{a}}$ \\
\hline $\mathrm{C} 18: 3(9 t, 12 t, 15 c+9 t, 12 c, 15 t)$ & $0.68 \pm 0.01^{\mathrm{a}}$ & $0.68 \pm 0.01^{\mathrm{a}}$ & $0.68 \pm 0.01^{\mathrm{a}}$ & $0.67 \pm 0.01^{\mathrm{a}}$ & $0.66 \pm 0.01^{\mathrm{a}}$ & $0.67 \pm 0.01^{\mathrm{a}}$ \\
\hline $\mathrm{C} 18: 3,9 \mathrm{c}, 12 \mathrm{c}, 15 \mathrm{t}$ & $1.05 \pm 0.02^{\mathrm{d}}$ & $1.23 \pm 0.02^{\mathrm{b}}$ & $1.30 \pm 0.02^{\mathrm{a}}$ & $1.10 \pm 0.02^{\mathrm{c}}$ & $1.14 \pm 0.02^{c}$ & $1.10 \pm 0.02^{\mathrm{c}}$ \\
\hline Total trans-C18:3 & $1.73 \pm 0.03^{\mathrm{c}}$ & $1.91 \pm 0.00^{\mathrm{a}, \mathrm{b}}$ & $1.98 \pm 0.09^{\mathrm{a}}$ & $1.77 \pm 0.05^{\mathrm{b}, \mathrm{c}}$ & $1.80 \pm 0.08^{\mathrm{b}}$ & $1.78 \pm 0.06^{b, c}$ \\
\hline TTFA $^{\mathrm{D}}$ & $3.04 \pm 0.06^{\mathrm{e}}$ & $4.47 \pm 0.08^{\mathrm{c}}$ & $4.87 \pm 0.10^{\mathrm{a}}$ & $4.53 \pm 0.08^{\mathrm{b}, \mathrm{c}}$ & $4.14 \pm 0.07^{\mathrm{d}}$ & $4.73 \pm 0.09^{\mathrm{a}, \mathrm{b}}$ \\
\hline
\end{tabular}

${ }^{\mathrm{A} C o n t r o l: ~ f r e s h ~ o i l ~ f r o m ~ u n e x t r u d e d ~ s o y b e a n ~ f l a k e s . ~}$

${ }^{\mathrm{B}}$ Means of duplicate analyses \pm standard deviation.

${ }^{\mathrm{C}} \mathrm{ND}$ : not detected.

${ }^{D}$ TTFA: total of trans fatty acids.

${ }^{\mathrm{a}-\mathrm{f}}$ Symbols bearing different letters in the same row are significantly different $(P<0.05)$.

TABLE 4: Trans fatty acid composition of soybean oil extracted by EAEP from extrudates at various screw rotational speeds under the condition of fixed extrusion temperature $\left(100^{\circ} \mathrm{C}\right)$ and feed moisture $(14 \%)$.

\begin{tabular}{|c|c|c|c|c|c|c|}
\hline \multirow{2}{*}{ Fatty acids ${ }^{\mathrm{B}}(\mathrm{g} / 100 \mathrm{~g})$} & \multicolumn{6}{|c|}{ Screw rotational speed (rpm) (pressure (bar)) } \\
\hline & Control $^{\mathrm{A}}(1.0133)$ & $100(14.9382)$ & $200(2.2745)$ & $300(0.2432)$ & $400(0.2841)$ & $500(0.4299)$ \\
\hline $\mathrm{C} 18: 1,9 \mathrm{t}$ & $0.57 \pm 0.01^{\mathrm{e}}$ & $1.73 \pm 0.03^{\mathrm{c}}$ & $2.09 \pm 0.04^{\mathrm{a}}$ & $1.62 \pm 0.03^{\mathrm{d}}$ & $1.73 \pm 0.03^{\mathrm{c}}$ & $1.99 \pm 0.04^{\mathrm{a}, \mathrm{b}}$ \\
\hline $\mathrm{C} 18: 2,9 \mathrm{c}, 12 \mathrm{t}$ & $0.64 \pm 0.01^{c}$ & $0.71 \pm 0.01^{\mathrm{b}}$ & $0.74 \pm 0.01^{\mathrm{a}}$ & $0.75 \pm 0.01^{\mathrm{a}}$ & $0.61 \pm 0.01^{\mathrm{c}}$ & $0.75 \pm 0.01^{\mathrm{a}}$ \\
\hline $\mathrm{C} 18: 2,9 \mathrm{t}, 12 \mathrm{c}$ & $1.05 \pm 0.02^{\mathrm{a}}$ & $0.08 \pm 0.01^{\mathrm{b}}$ & $0.07 \pm 0.01^{\mathrm{b}}$ & $0.08 \pm 0.01^{\mathrm{b}}$ & $0.10 \pm 0.01^{\mathrm{b}}$ & $0.08 \pm 0.01^{\mathrm{b}}$ \\
\hline Total trans- C18:2 & $0.74 \pm 0.01^{c}$ & $0.78 \pm 0.01^{\mathrm{b}}$ & $0.81 \pm 0.02^{\mathrm{a}, \mathrm{b}}$ & $0.84 \pm 0.02^{\mathrm{a}}$ & $0.70 \pm 0.00^{\mathrm{d}}$ & $0.82 \pm 0.00^{\mathrm{a}}$ \\
\hline $\mathrm{C} 18: 3(9 \mathrm{t}, 12 \mathrm{t}, 15 \mathrm{c}+9 \mathrm{t}, 12 \mathrm{c}, 15 \mathrm{t})$ & $0.68 \pm 0.01^{\mathrm{a}}$ & $0.66 \pm 0.01^{\mathrm{a}}$ & $0.68 \pm 0.01^{\mathrm{a}}$ & $0.69 \pm 0.01^{\mathrm{a}}$ & $0.65 \pm 0.01^{\mathrm{a}}$ & $0.68 \pm 0.01^{\mathrm{a}}$ \\
\hline $\mathrm{C} 18: 3,9 \mathrm{c}, 12 \mathrm{c}, 15 \mathrm{t}$ & $1.05 \pm 0.02^{\mathrm{c}}$ & $1.20 \pm 0.02^{\mathrm{b}}$ & $1.30 \pm 0.02^{\mathrm{a}}$ & $1.32 \pm 0.02^{\mathrm{a}}$ & $1.05 \pm 0.02^{\mathrm{c}}$ & $1.24 \pm 0.02^{\mathrm{b}}$ \\
\hline Total trans-C18:3 & $1.73 \pm 0.03^{c}$ & $1.87 \pm 0.03^{\mathrm{a}, \mathrm{b}}$ & $1.98 \pm 0.04^{\mathrm{a}}$ & $2.00 \pm 0.04^{\mathrm{a}}$ & $1.70 \pm 0.03^{c}$ & $1.93 \pm 0.05^{\mathrm{a}}$ \\
\hline TTFA $^{\mathrm{C}}$ & $3.04 \pm 0.06^{\mathrm{e}}$ & $4.38 \pm 0.08^{\mathrm{c}}$ & $4.87 \pm 0.10^{\mathrm{a}}$ & $4.46 \pm 0.08^{c}$ & $4.13 \pm 0.07^{\mathrm{d}}$ & $4.74 \pm 0.09^{\mathrm{b}}$ \\
\hline
\end{tabular}

${ }^{\mathrm{A}}$ Control: fresh oil from unextruded soybean flakes.

${ }^{\mathrm{B}}$ Means of duplicate analyses \pm standard deviation.

$\mathrm{C}_{\text {TTFA: }}$ total of trans fatty acids.

${ }^{\mathrm{a}-\mathrm{f}}$ Symbols bearing different letters in the same row are significantly different $(P<0.05)$.

By comparing the various trans-forms of fatty acids, oleic acid was the most susceptible to formation during extruding process.

\subsubsection{Effect of Extrusion Temperature. The changes in the TFA} composition of soybean oil extracted from extrudates under various extrusion temperatures $\left(80,100,120,140\right.$, and $\left.160^{\circ} \mathrm{C}\right)$ were shown in Table 2. Compared to the control samples, no continuous increase or decrease in TFA content was observed with increasing extrusion temperature. This was due to the instability of different types of TFAs [22] and discontinuity of chamber pressure. After extrusion at $80^{\circ} \mathrm{C}$, the sharp increase of total trans-linoleic acid (by $1.70 \mathrm{~g} / 100 \mathrm{~g}$ ) could mostly be attributed to the increase of chamber pressure from 1.0133 bars to 9.9113 bars. However, the amounts of trans-oleic acid (C18:1, 9t) after extruding at $100^{\circ} \mathrm{C}$ were significantly increased by $1.68 \mathrm{~g} / 100 \mathrm{~g}$, whereas the total amounts of translinoleic acid were significantly decreased by $1.63 \mathrm{~g} / 100 \mathrm{~g}$. This shift phenomenon seemly suggested that part of translinoleic acid was transformed into trans-oleic acid. Although diverse changes occurred for different types of TFAs, the total amounts of TFA reached a maximum of $4.91 \mathrm{~g} / 100 \mathrm{~g}$ after extrusion at $160^{\circ} \mathrm{C}$. It could be found that, among these different levels of the extrusion temperature, the maximum amount of TTFA was 1.62 times that in the control sample, while the minimum amount of TTFA was 1.54 times that in the control sample. Although the change of every type of trans fatty acid was fluctuant, the range of this variation was not very great during extrusion with increasing temperature. Since the cis- to trans-isomerization may occur at $150^{\circ} \mathrm{C}$ [23], the formation of trans fatty acids was likely exacerbated by the combined effects of pressure and high temperature. A previous study reported that only $1 \%$ to $2 \%$ of the unsaturated fatty acids were converted to the trans-form during the extrusion of cornmeal $[16,24]$. After increasing extrusion temperature from $155^{\circ} \mathrm{C}$ to $171^{\circ} \mathrm{C}$, the amount of trans fatty acid increased from $1 \%$ to $1.5 \%[16,25]$.

3.1.3. Effect of Feed Moisture. The changes in TFA composition of soybean oil extracted from extrudates under various 
feed moisture levels $(10,14,18,22$, and $26 \%)$ were presented in Table 3. After extrusion at a low content of feed moisture $(10 \%)$, a distinct increase of $1.27 \mathrm{~g} / 100 \mathrm{~g}$ and $0.18 \mathrm{~g} / 100 \mathrm{~g}$ was observed for trans-oleic acid (C18:1, 9t) and trans-linolenic acid $(\mathrm{C} 18: 3,9 \mathrm{c}, 12 \mathrm{c}, 15 \mathrm{t})$, respectively. This is a result of a higher shear force, chamber pressure, and longer residence time at a lower moisture level [26]. After increasing the feed moisture level to $14 \%$, the amounts of all the five types of TFAs exhibited an increasing trend. However, when the feed moisture was increased continuously, the total amount of these TFAs began to reduce, probably because the force, required to push the wet mass through the die, was reduced when increasing the feed moisture content. Simultaneously, the friction between raw material and screw shaft started to decrease [27]. Similarly, the minimum and maximum of the TTFA with different feed moisture were compared with those in the control sample. This variance based on the TTFA in the control sample, and it ranged from 1.36 to 1.60 times that in the control sample. The effect of the feed moisture was shown to be bidirectional, which was confirmed by the result of the two opposite effects of moisture content on the rheology of the feed material in the barrel and die of the extruder [28]. Surprisingly, undetected phenomenon of the trans-linoleic acid (C18:2, 9t, 12c) appeared twice, when the extrusion feed moisture was $10 \%$ and $22 \%$, respectively. These results indicated that the trans-linoleic acid $(\mathrm{C} 18: 2,9 \mathrm{t}, 12 \mathrm{c})$ was not stable, which was confirmed by a previous study [29]. The calculated energy difference between the cis- and translinoleic acids was equal to $13.2 \mathrm{~kJ} / \mathrm{mol}$, whereas the energy difference between the cis-and trans-forms of oleic acid was $37 \mathrm{~kJ} / \mathrm{mol}$.

3.1.4. Effect of Screw Rotational Speed. The changes in TFA composition of soybean oil extracted from extrudates under various screw rotational speeds $(100,200,300,400$, and $500 \mathrm{rpm}$ ) were shown in Table 4. Again, the levels of the main five types of TFAs in soybean oil changed significantly after altering the screw rotational speeds. A sharp increase of $1.16 \mathrm{~g} / 100 \mathrm{~g}$ occurred for trans-oleic acid $(\mathrm{C} 18: 1,9 \mathrm{t})$ when extruding at a screw rotational speed of $100 \mathrm{rpm}$. Although the screw rotational speed was low, the high chamber pressure might promote the isomerization of the different TFAs. Moreover, when increasing the screw rotational speed to $200 \mathrm{rpm}$, the levels of trans-oleic acid (C18:1, 9t) and the total TFAs were up to their maximum of 2.09 and $4.87 \mathrm{~g} / 100 \mathrm{~g}$, respectively. This phenomenon was the same as that observed for the effect of feed moisture content. However, the maximum levels of the total linoleic acid $(0.84 \mathrm{~g} / 100 \mathrm{~g})$ and the total translinolenic acid $(2.00 \mathrm{~g} / 100 \mathrm{~g})$ were observed after extruding at a screw rotational speed of $300 \mathrm{rpm}$. The maximum level for any type of TFA was not received at the maximum of screw rotational speed. This result proved that TFAs could undergo degradation under the severe experimental conditions used [20]. Meanwhile, compared with the effect of feed moisture, the same times of the amount of TTFA in the control were found, respectively, for the minimum (1.36) and maximum (1.60) of TTFA under different screw rotational speeds.

\section{Conclusion}

Dehulled full-fat soybean flakes were extruded for the extraction of soybean oil to study the effect of the extrusion process parameters, barrel temperature, feed moisture, and screw rotational speed, on the content of trans fatty acid (TFA). By comparing the results shown above, we can conclude that extrusion technology could increase the formation of TFA. All the levels of the extrusion variables caused diverse fluctuation of the amount of TFA. Although the gap between the minimum and the maximum of total amount of TFA was smaller under the variable of extrusion temperature than that of the other two variables (feed moisture and screw rotational speed), the increased magnitude with effect of the first level of extrusion temperature was greater than that of the other two variables. In other words, the sudden extrusion temperature could transiently increase the formation of TFA in the oil. In summary, the content of TFA in soybean oil could be controlled by changing the extrusion parameters. To comprehensively explore the effect of the extrusion process, further studies are needed to investigate the thermal properties of the TFAs and explore appropriate extrusion condition for the lowest amount of TFA.

\section{Conflict of Interests}

The authors have declared no conflict of interests.

\section{Authors' Contribution}

Hongxia Feng and Xiaonan Sui contributed equally to this paper.

\section{Acknowledgments}

The authors are grateful to the National High-Tech R\&D Program of China (863 Program) (2013AA102104) for the financial support and to the Ministry of Agriculture of Modern Technology System Projects of the Soybean Industry (nycytx004) for funding this paper.

\section{References}

[1] W. Tsuzuki, A. Matsuoka, and K. Ushida, "Formation of trans fatty acids in edible oils during the frying and heating process," Food Chemistry, vol. 123, no. 4, pp. 976-982, 2010.

[2] M. C. Craig-Schmidt, "World-wide consumption of trans fatty acids," Atherosclerosis Supplements, vol. 7, no. 2, pp. 1-4, 2006.

[3] J.-C. Hou, L.-Z. Jiang, and C.-W. Zhang, "Effects of frying on the trans-fatty acid formation in soybean oils," European Journal of Lipid Science and Technology, vol. 114, no. 3, pp. 287-293, 2012.

[4] J. Hou, F. Wang, Y. Wang, J. Xu, and C. Zhang, "Assessment of trans fatty acids in edible oils in China," Food Control, vol. 25, no. 1, pp. 211-215, 2012.

[5] D. B. Allison, S. K. Egan, L. M. Barraj, C. Caughman, M. Infante, and J. T. Heimbach, "Estimated intakes of trans fatty and other fatty acids in the US population," Journal of the American Dietetic Association, vol. 99, no. 2, pp. 166-174, 1999. 
[6] M. Roe, H. Pinchen, S. Church et al., "Trans fatty acids in a range of UK processed foods," Food Chemistry, vol. 140, no. 3, pp. 427431, 2013.

[7] S. Gunawan, E. Melwita, and Y.-H. Ju, "Analysis of trans-cis fatty acids in fatty acid steryl esters isolated from soybean oil deodoriser distillate," Food Chemistry, vol. 121, no. 3, pp. 752-757, 2010.

[8] K. A. Campbell, C. E. Glatz, L. A. Johnson et al., "Advances in aqueous extraction processing of soybeans," Journal of the American Oil Chemists' Society, vol. 88, no. 4, pp. 449-465, 2011.

[9] C. Dufaure, J. Leyris, L. Rigal, and Z. Mouloungui, "Twin-screw extruder for oil extraction, I: direct expression of oleic sunflower seeds," JAOCS, Journal of the American Oil Chemists' Society, vol. 76, no. 9, pp. 1073-1079, 1999.

[10] F. Elstner, "Expanders used for pretreatment of oilseeds," FettLipid, vol. 99, pp. 147-152, 1997.

[11] I. Amalia Kartika, P. Y. Pontalier, and L. Rigal, "Twin-screw extruder for oil processing of sunflower seeds: thermo-mechanical pressing and solvent extraction in a single step," Industrial Crops and Products, vol. 32, no. 3, pp. 297-304, 2010.

[12] B. P. Lamsal, P. A. Murphy, and L. A. Johnson, "Flaking and extrusion as mechanical treatments for enzyme-assisted aqueous extraction of oil from soybeans," Journal of the American Oil Chemists' Society, vol. 83, no. 11, pp. 973-979, 2006.

[13] R. T. Patil and N. Ali, "Effect of pre-treatments on mechanical oil expression of soybean using a commercial oil expeller," International Journal of Food Properties, vol. 9, no. 2, pp. 227236, 2006.

[14] T. Wang and L. A. Johnson, "Survey of soybean oil and meal qualities produced by different processes," Journal of the American Oil Chemists' Society, vol. 78, no. 3, pp. 311-318, 2001.

[15] J. C. Cheftel, "Nutritional effects of extrusion-cooking," Food Chemistry, vol. 20, no. 4, pp. 263-283, 1986.

[16] J. A. Maga, "Cis-trans fatty acid ratios as influenced by product temperatures of extrusion-cooking," Lebensmittel-Wissenschaft \& Technologie, vol. 11, pp. 183-184, 1978.

[17] C. Xu, H. Lee, B. Lee et al., "Production of lean beef containing a high content of trans-10, cis-12 conjugated linoleic acid by feeding a high-temperature-micro-time-treated diet with extruded soybean," Bioscience, Biotechnology and Biochemistry, vol. 70, no. 11, pp. 2589-2597, 2006.

[18] J. M. L. N. de Moura Bell, D. Maurer, L. Yao, T. Wang, S. Jung, and L. A. Johnson, "Characteristics of oil and skim in enzymeassisted aqueous extraction of soybeans," Journal of the American Oil Chemists' Society, vol. 90, no. 7, pp. 1079-1088, 2013.

[19] Y. Li, Y. Zhang, M. Wang, L. Jiang, and X. Sui, "Simplex-centroid mixture design applied to the aqueous enzymatic extraction of fatty acid-balanced oil from mixed seeds," Journal of the American Oil Chemists' Society, vol. 90, no. 3, pp. 349-357, 2013.

[20] W. H. Liu, B. Stephen Inbaraj, and B. H. Chen, "Analysis and formation of trans fatty acids in hydrogenated soybean oil during heating," Food Chemistry, vol. 104, no. 4, pp. 1740-1749, 2007.

[21] R. L. Wolff, "trans-Polyunsaturated fatty acids in French edible rapeseed and soybean oils," Journal of the American Oil Chemists' Society, vol. 69, no. 2, pp. 106-110, 1992.

[22] C. M. M. Alfaia, P. J. L. C. Ribeiro, M. J. P. Trigo et al., "Irradiation effect on fatty acid composition and conjugated linoleic acid isomers in frozen lamb meat," Meat Science, vol. 77, no. 4 , pp. 689-695, 2007.
[23] C. Li, Y. Zhang, S. Li et al., "Mechanism of formation of trans fatty acids under heating conditions in triolein," Journal of Agricultural and Food Chemistry, vol. 61, pp. 10392-10397, 2013.

[24] M. E. Camire, A. Camire, and K. Krumhar, "Chemical and nutritional changes in foods during extrusion.," Critical Reviews in Food Science and Nutrition, vol. 29, no. 1, pp. 35-57, 1990.

[25] X. Tiemin, The Experimental Studies on Quality of Oil and Cake Based Day-Extrusion Repeseed, Northeast Agricultural University, 2008.

[26] F. L. Chen, Y. M. Wei, B. Zhang, and A. O. Ojokoh, "System parameters and product properties response of soybean protein extruded at wide moisture range," Journal of Food Engineering, vol. 96, no. 2, pp. 208-213, 2010.

[27] W. Y. Kang Lining, Z. Bo, Z. Duoyong, Z. Cuan, and Z. Xuewei, "Effects of technological parameters on system pressure and torque in soy protein texturization by high moisture extrusion," Journal of the Chinese Cereals and Oils Association, vol. 22, pp. 43-49, 2007.

[28] M. Seker, "Residence time distributions of starch with high moisture content in a single-screw extruder," Journal of Food Engineering, vol. 67, no. 3, pp. 317-324, 2005.

[29] A. Li, B. Yuan, W. Li, F. Wang, and Y. Ha, “Thermally induced isomerization of linoleic acid in soybean oil," Chemistry and Physics of Lipids, vol. 166, no. 1, pp. 55-60, 2013. 

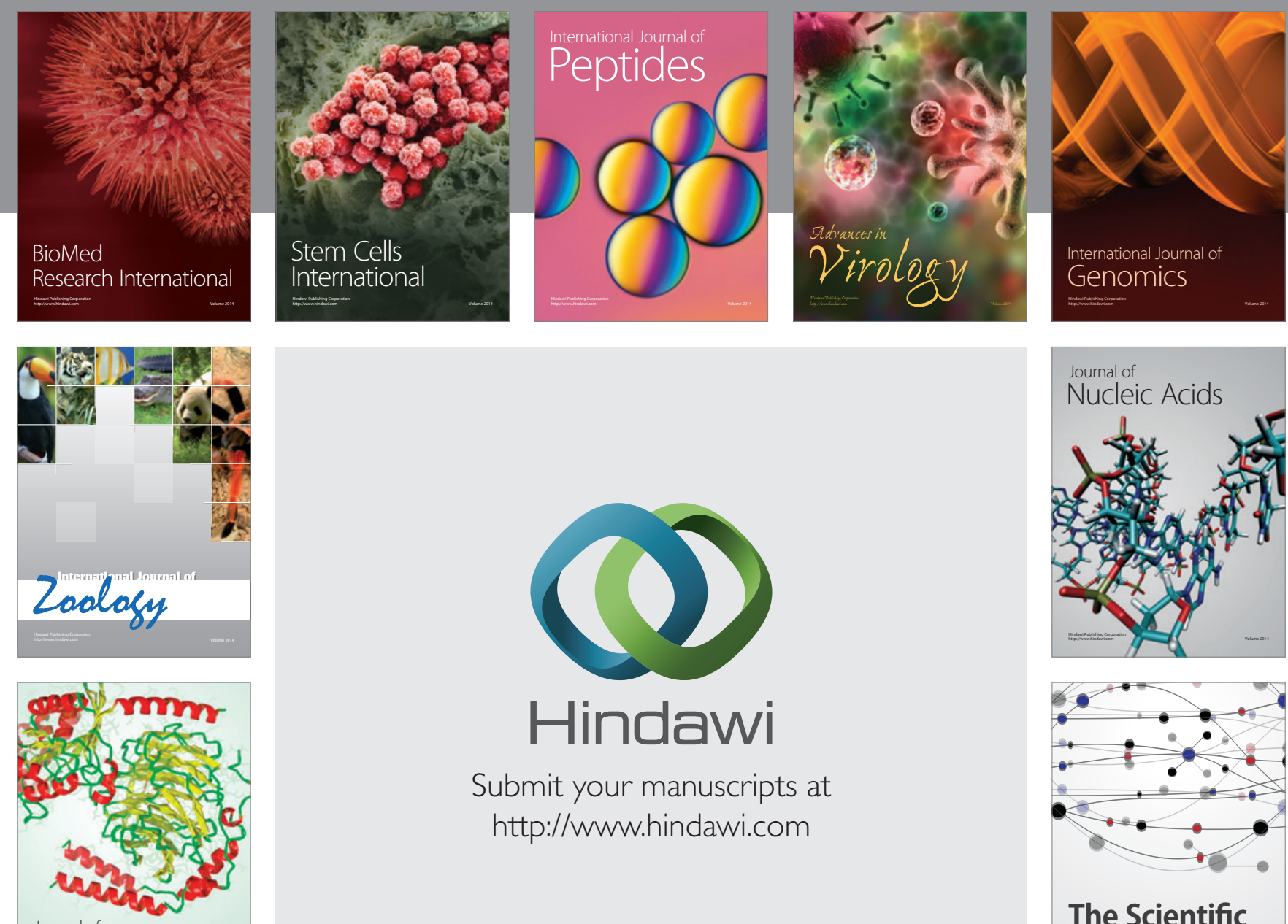

Submit your manuscripts at

http://www.hindawi.com

Journal of
Signal Transduction
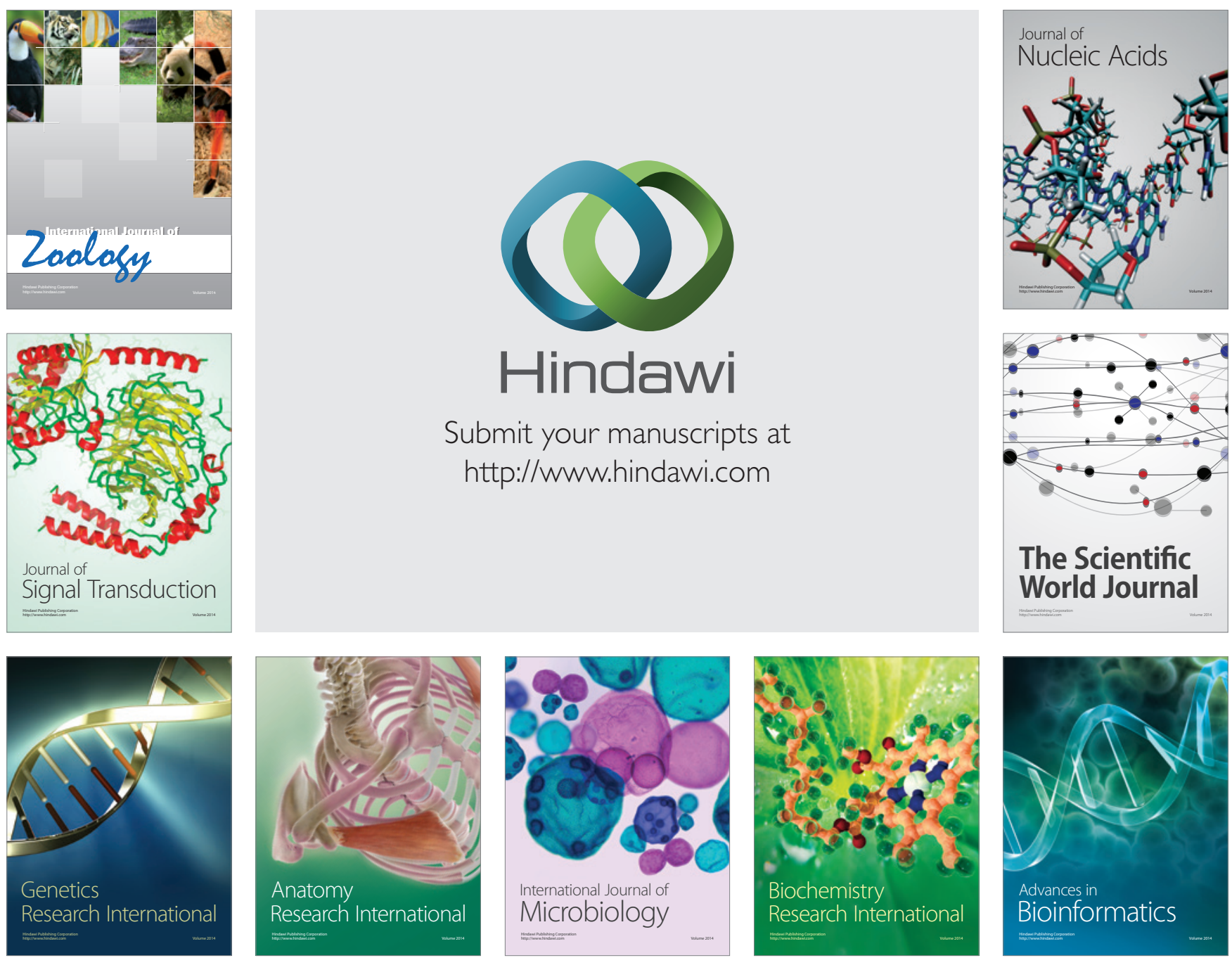

The Scientific World Journal
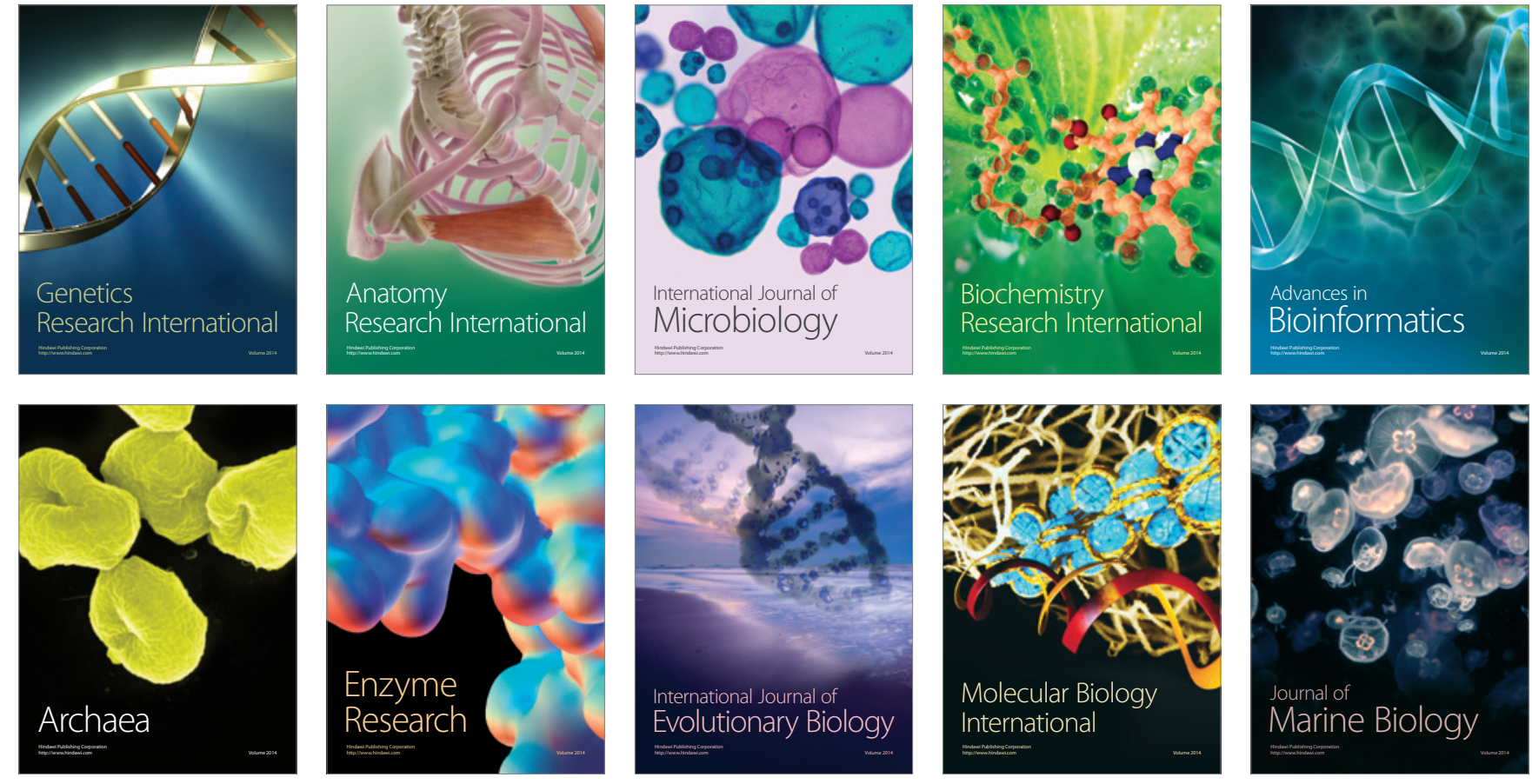